\title{
Agrapana Melesat: Pengembangan Sumber Kalong Menjadi Rintisan Desa Wisata dengan Pendekatan Community Based Tourism
}

\section{Sumani*1, Markus Apriono², Ika Barokah Suryaningsih³, Kristian S. W. Nugraha4}

\author{
1,2,3,4Jurusan Manajemen, Fakultas Ekonomi dan Bisnis, Universitas Jember, Indonesia \\ *e-mail: sumani@unej.ac.id ${ }^{1}$ markoesapriono.feb@unej.ac.id ${ }^{2}{ }_{\text {_barokah.feb@unej.ac.id }}^{3}$, \\ $\underline{\text { kristian.feb@unej.ac.id }}^{4}$
}

\begin{abstract}
Abstrak
Desa Sumber Kalong merupakan salah satu desa dengan basis agraris yang memiliki potensi sebagai desa wisata. Potensi yang dikembangkan yaitu berupa sumber mata air yang dibentuk menjadi waduk. Posisi sumber mata air sebagai salah satu sarana irigasi utama desa Sumber Kalong berdampingan dengan hamparan sawah yang luas di samping waduk sehingga dapat dijadikan satu paket wisata. Keunggulan lain desa Sumber Kalong yaitu lokasi yang cukup strategis yakni sekitar 30 menit dari pusat kecamatan Wonosari dengan akses jalan yang mudah. Keunggulan tersebut rupanya tidak seimbang dengan kondisi pengelola yaitu keterbatasan sumber daya manusia, keterbatasan dalam aspek manajerial dan menentukan strategi pengembangan dan ketidakpedulian masyarakat tentang pentingnya desa wisata bagi kondisi perekonomian wilayah. Kegiatan pengabdian yang dilakukan menggunakan pendekatan deskriptif kualitatif yaitu berusaha untuk memahami fenomena yang ada dan dikonstruksikan secara spesifik sesuai kondisi nyata yang terjadi. Solusi yang ditawarkan adalah sosialisasi dan pendampingan tentang optimalisasi potensi Desa Sumber Kalong khususnya Agrapana, pelatihan dalam hospitality dan kesadaran menjaga kebersihan, dan penambahan spot selfie sebagai salah satu upaya penambahan fasilitas wisata. Hasil yang dicapai pada pengabdian kepada masyarakat ini yaitu adalah pengenalan pengelolaan BUMDES; peningkatan pemgetahuan dan skill dalam pengelolaan area wisata; penambahan sarana kebersihan disekitar wisata Agrapana: dan Pembangunan spot selfie untuk menarik lebih banyak pengunjung untuk datang ke Wisata Agrapana Desa Sumber Kalong untuk mewujudkan Agrapana Melesat.
\end{abstract}

Kata kunci: Agrapana, Community Based Tourism, Sumber Kalong

\begin{abstract}
Sumber Kalong Village is one of the villages with an agricultural basis that is a tourist village. The prospect that will be developed is in the form of springs formed into reservoirs. The position of the spring as one of the leading irrigation facilities in the village of Sumber Kalong is side by side with a vast expanse of rice fields next to the reservoir so that it can be used as a tour package. Another advantage of Sumber Kalong village is its strategic location, about 30 minutes from the center of the Wonosari sub-district with easy road access. These advantages are not matched by the management conditions, namely limited human resources, minor managerial aspects, the determination of development strategies, and public ignorance of the importance of tourist villages for regional economic conditions. Service activities are carried out using a qualitative descriptive approach, which tries to understand the existing phenomena and is constructed explicitly according to the actual conditions. The solutions offered are socialization and assistance in optimizing the potential of Sumber Kalong Village, especially Agrapana, training on friendliness and awareness of maintaining cleanliness, and adding selfie spots to add tourist facilities. The results achieved in this community service are introducing BUMDES management, increasing knowledge and skills in the management of tourist areas, cleaning facilities around Agrapana tourism, and developing selfie spots to attract more visitors to Agrapana Tourism in Sumber Kalong Village to realize Agrapana Melesat.
\end{abstract}

Keywords: Agrapana, Community Based Tourism, Sumber Kalong

\section{PENDAHULUAN}

Desa wisata merupakan salah satu program nasional yang digaungkan oleh Kementerian Pariwisata dan Ekonomi Kreatif serta banyak diadaptasi menjadi program wilayah di tingkat kabupaten. Desa wisata sejatinya adalah pemanfaatan keunikan dan cirikhas desa menjadi suatu atraksi yang dapat dikembangkan dan berkontribusi bagi masyarakat (Ma'ruf, 2020; Permadi et al., 2020). Pariwisata merupakan suatu bidang dengan multiplier effect yang luas (Soekarya, 
2011), jika dikerjakan dengan sungguh-sungguh maka dapat menjadi faktor pengungkit bagi sektor lain khususnya ekonomi dan ketenagakerjaan.

Berkembangnya pariwisata di suatu daerah akan mendatangkan banyak manfaat bagi masyarakat, yakni secara ekonomis, sosial dan budaya. Namun, jika pengembangannya tidak dipersiapkan dan dikelola dengan baik, justru akan menimbulkan berbagai permasalahan yang menyulitkan atau bahkan merugikan masyarakat (Giampiccoli et al., 2020). Untuk menjamin supaya pariwisata dapat berkembang secara baik dan berkelanjutan serta mendatangkan manfaat bagi manusia dan meminimalisasi dampak negatif yang mungkin timbul maka pengembangan pariwisata perlu didahului dengan kajian yang mendalam, yakni dengan melakukan penelitian terhadap semua sumber daya pendukungnya. Pengembangan suatu desa wisata harus memperhatikan beberapa hal utama yaitu keunikan dan kedekatan dengan alam serta cirikhas budaya yang ada (Dewi et al., 2013; Ma'ruf, 2020).

Membangun desa wisata tidak sekedar membangun suatu destinasi dan atraksi semata, namun membangun suatu pola kehidupan baru yang sedikit banyak akan mengubah kehidupan warga desa (Suryaningsih et al., 2020). Tantangannya adalah bagaimana bisa membangun suatu destinasi tanpa merusak struktur masyarakat dan tanpa merusak kearifan lokal serta kebiasan warga desa pada umumnya. Keberlanjutan dan pemberdayaan adalah keniscayaan dalam proses membangun desa wisata (Nugraha, 2019; Syafi'i \& Suwandono, 2015) yang terkonsep menjadi community based tourism.

Sumber Kalong merupakan sebuah desa di Kecamatan Wonosari Kabupaten Bondowoso Jawa Timur. Desa dengan luas wilayah sekitar 223,708 ha berada pada posisi strategis yaitu pada poros utama jalur Bondosowo - Situbondo sekaligus sebagai jalur alternatif menuju wisata Kawah Wurung dan Kawah Ijen. Sebagai suatu desa dengan mayoritas penduduk berprofesi sebagai petani menjadikan Sumber Kalong menjadi desa basis pertanian di Bondowoso. Kebiasaan warga desa Sumber Kalong umumnya berkutat pada kehidupan desa agraris lainnya dan aktivitas ekonomi juga tidak jauh pada aktivitas agraris lainnya seperti berkebun, memelihara ikan dan unggas.

Agrapana merupakan salah satu program desa terkait dengan wisata desa. Memanfaatkan potensi sumber air yang besar selain digunakan sebagai irigasi pertanian akhirnya mulai dikembangkan menjadi wahana wisata berbasis desa. Modal awal bangunan yang dimiliki hanya dua kolam besar yang oleh warga desa disebut waduk sebagai penampungan dan kontrol debit air dan akhirnya dikembangkan dengan membangun beberapa gazebo diatas kolam air tersebut. Agrapana desa Sumber Kalong memiliki beberapa keunggulan yaitu dari sisi atraksi, Agrapana dibangun dari modal yang sudah ada di desa tersebut yaitu sumber air dan kolam air, akses yang terjangkau dari jalan utama, yaitu sekitar 15 menit dari poros Bondowoso - Situbondo.

Sebagai usaha menuju desa wisata yang mandiri, perangkat desa Sumber Kalong pernah berinisiatif membangun kolam pancing namun tidak bertahan lama karena kurangnya perhatian dan pemahaman dari warga setempat. Mengingat pelibatan masyarakat lokal merupakan kunci utama dalam pembangunan desa wisata berbasis community based tourism (Permadi et al., 2020), maka masyarakat sebagai pemilik modal desa harus terlibat dalam pembangunan dan perawatan asset desa termasuk didalamnya desa wisata. Tantangan lain yang dihadapi adalah warga desa belum memahami apa esensi desa wisata dan mengapa harus desa wisata, sehingga belum mencapai satu suara dalam hal pembangunan desa wisata.

Berdasarkan hasil observasi terdapat beberapa data yang diperoleh terkait dengan potensi wisata Agrapana. Agrapana memiliki luas kolam atau waduk yaitu 3895,9 m2. Perangkat desa bersama BUMDES Sumber Kalong berupaya membuat draft awal siteplan pengembangan wisata Agrapana dengan tagline Agrapana Melesat sesuai dengan jargon kabupaten Bondowoso yaitu Bondowoso Melesat. Rencana pengembangan wisata Agrapana akan dibagi menjadi tiga bagian dengan maksud untuk mempermudah dalam pendetailan ukuran setiap area. Menurut ketua BUMDES Sumber Kalong, desain obyek wisata hanya digunakan sebagai kelengkapan dokumen desa yang merupakan salah satu syarat mengadakan pembangunan pengembangan wisata desa. Selain itu, rencana pengembangan kedepan masih sebatas ide dan belum tertuang dalam suatu dokumen. 
Sesuai dengan observasi dan penggalian masalah, didapati bahwa terdapat beberapa permasalahan dalam membangun desa wisata di Sumber Kalong. Permasalahan tersebut dapat diidentifikasi sebagai berikut: (1) kurang optimalnya BUMDes dalam pengelolaan obyek wisata, karena wisata tidak hanya soal adanya destinasi dan kemampuan membangun saja, namun bagaimana destinasi tersebut mampu bertahan dan berkelanjutan; (2) sumber daya manusia yang kurang paham dan care terhadap pembangunan desa wisata. Sumber daya disini termasuk masyarakat desa yang masih belum paham apa manfaat desa wisata dan bagaimana menjadi masyarakat yang sadar wisata; (3) masalah sumber daya manusia terkait pegawai yang bertugas di obyek wisata, umumnya pegawai yang bertugas hanya sekedar bekerja saja tanpa tahu bagaimana aspek bisnis hospitality; (4) masih minimnya sarana kebersikan dan titik daya tarik seperti spot selfie; (5) pandemi COVID-19 yang menjadikan dunia wisata khususnya wisata desa mati suri.

Melihat kondisi existing wisata Agrapana Desa Sumber Kalong, maka pekerjaan utama yang harus dilakukan untuk mewujudkan Agrapana Melesat adalah membangun kesadaran mengenai pentingnya desa wisata dan manfaat desa wisata bagi masyarakat. Solusi yang disa ditawarkan adalah pendampingan dan penguatan kelembagaan khususnya kepada masyarakat dan BUMDes dengan pendekatan community based tourism. Salah satu fokus dalam kegiatan pengabdian berbasis desa binaan adalah pendampingan mengenai konsep community based tourism yaitu memanfaatkan dan memberdayakan masyarakat dalam pengelolaan wisata desa.

\section{METODE}

Kegiatan pengabdian yang dilakukan menggunakan pendekatan deskriptif kualitatif. Pendekatan kualitatif yang digunakan berusaha untuk memahami fenomena yang ada dan bukan menjurus pada suatu hipotesis semata dan dikonstruksikan secara spesifik sesuai kondisi nyata yang terjadi (Ghony \& Almanshur, 2012). Aktivitas pengabdian masyarakat yang dilakukan berfokus pada bagaimana mengembangkan desa wisata dengan memperhatikan keseluruhan keadaan secara holistik dan dideskripsikan menjadi suatu rangkaian pembahasan yang logis.

Pengumpulan data menggunakan cara FGD atau diskusi terpumpun dengan melibatkan pihak yang terkait yaitu pemerintah desa dalam hal ini kepala desa, ketua BUMDes dan ketua Pokdarwis, pengelola destinasi Agrapana dan perwakilan masyarakat. Selain aktivitas FGD, kegiatan pendampingan juga dilakukan baik kepada masyarakat sekitar maupun pendampingan manajerial kepada BUMDes dan pengelola destinasi Agrapana.

Secara teknis, aktivitas yang dilakukan pada pengabdian kepada masyarakat yaitu

\section{Sosialisasi program}

Pada awal pelaksanaan kegiatan, tim pelaksana akan melakukan survei ke tempat mitra untuk berdiskusi kembali sekaligus melihat kondisi lapangan secara langsung. Tim pelaksana dan mitra juga akan berkoordinasi terkait program pengabdian yang akan segera dilaksanakan.

2. Peningkatan pengetahuan mitra (penyuluhan) mengenai pemberdayaan BUMDES.

a. Brainstorming dan diskusi dengan memberikan materi tentang organisasi dan optimalisasi struktur organisasi.

b. Melakukan pendampingan penyusunan SOP dalam memperkuat tata kelola kelembagaan BUMDES terutama dalam pemasaran Wisata Agrapana.

3. Edukasi mengenai konsep Community based tourism dan kesadaran masyarakat sekitar akan estetika tempat wisata dengan memberikan penyuluhan tentang peran dan manfaat potensi wisata Agrapana dalam memberikan kontribusi ekonomis.

4. Pendampingan kebersihan lingkungan tempat wisata, dan fasilitas daya tarik.

Pendampingan yang dilaksanakan dalam bentuk observasi langsung yang bertujuan untuk mengetahui dan memastikan apakah mitra sudah dapat melakukan kegiatan pengelolaan tempat wisata terkait kebersihan lingkungan. kegiatan pendampingan ini diharapkan dapat meningkatkan kesadaran baik pengelola wisata maupun masyarakat sekitarnya dalam 
menjaga kebersihan dengan melakukan penambahan tempat sampah disekitar wisata Agrapana serta memberikan fasilitas lain yang diperlukan adalah pembangunan spot selfie sederhana dirasa perlu untuk menarik lebih banyak pengunjung untuk datang ke Wisata Agrapana Desa Sumber Kalong.

\section{HASIL DAN PEMBAHASAN}

Kegiatan pengabdian kepada masyarakat disusun dalam berbagai program-program dengan tujuan menjawab permasalahan yang ada. Kegiatan pengabdian kepada masyarakat berbasis desa binaan dimulai dari sosialisasi program dengan tujuan menjaring pendapat dan menggali informasi mengenai kondisi Desa Sumber Kalong dan Agrapana, selain itu juga sebagai bentuk observasi awal dalam menentukan aktivitas lanjutan yang diperlukan. Sosialisasi program lebih menekankan pada survei awal dengan metode brainstorming dan aktif mendengar kebutuhan perangkat desa dan BUMDes setempat. Respon awal yang didapat yaitu pihak desa dan BUMDes sangat antusias dan aktif berdiskusi mengenai peluang pembangunan dan pengembangan destinasi Agrapana di desa Sumber Kalong.

Hasil diskusi dan sosialisasi program didapat bahwa kondisi existing Agrapana saat ini dalam posisi mangkrak karena pandemi COVID-19. Padahal pada saat sebelum pandemi COVID19 Agrapana dapat memiliki pendapatan yang cukup dari penjualan makanan dan minuman ringan dengan mengandalkan gazebo dan peralatan yang ada. Sebagai suatu rintisan desa wisata maka sumber daya yang digunakan juga masih sederhana dan belum ada kualifikasi kompetensi terkait hospitality. Sehingga ketika kondisi pandemi dan pemberlakuan pembatasan kegiatan masyarakat menjadikan Agrapana tutup sementara dan banyak gazebo sebagai atraksi utama mengalam kerusakan seperti yang tampak pada Gambar 1 berikut.

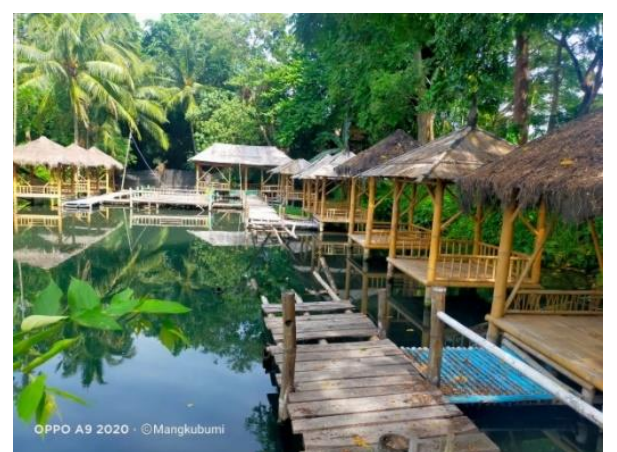

(a)

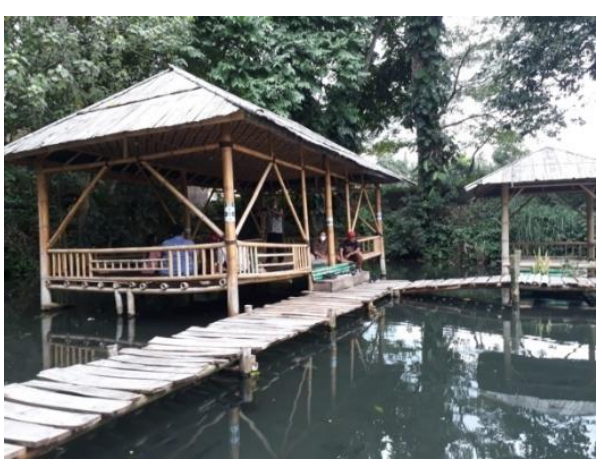

(b)

Gambar 1. a) Kondisi Agrapana pada saat pandemi b) Kondisi Agrapana sebagai output kegiatan pengabdian kepada masyarakat

Sumber: Dokumen pribadi (2021)

Penyebab rusaknya gazebo dan jembatan penghubung ke tiap gazebo adalah karena tidak adanya perawatan akibat pendanaan yang kurang dan kurangnya kesadaran masyarakat dalam menjaga aset yang ada seperti membiarkan jembatan penghubung tersebut dijadikan tempat bermain anak-anak untuk berenang dan lompat-lompat di gazebo maupun jembatan penghubung yang ada. Pembiaran tersebut menjadikan kondisi Agrapana menjadi semakin terpuruk.

Setelah Sosialisasi dan FGD dilakukan, maka dalam rangka meningkatkan keberdayaan mitra dan mewujudkan Agrapana Melesat dilakukan peningkatan pengetahuan mitra khususnya tentang pemberdayaan BUMDes. Aktivitas yang dilakukan yaitu dengan melakukan pendampingan mengenai manajemen sederhana dan pengelolaan sederhana tempat wisata. Pendampingan dibutuhkan sebab dengan adanya pandemi banyak tenaga kerja yang keluar untuk mencari pekerjaan lain dan banyak pegawai baru yang tidak berpengalaman sehingga perlu pendampingan dan penguatan khususnya mengenai motivasi dan keorganisasian. Selain 
itu, Agrapana selama ini masih dibawah pengelolaan BUMDes dan belum terbentuk Pokdarwis yang tetap sehingga secara organisasi masih belum jelas tanggung jawab, kewenangan dan hak yang diberikan. Hasil pendampingan menunjukkan respon positif yaitu terbentuknya Pokdarwis yang dipersiapkan berbadan hukum dan telah diajukan pada Dinas Pariwisata, Pemuda dan Olahraga Kabupaten Bondowoso sebagai bentuk komitmen pengelola akan desa wisata. Selain itu, dengan adanya pengabdian masyarakat ini, mulai disusun SOP kelembagaan dan tata kelola destinasi wisata secara sederhana dengan target supaya pengelola dapat memahami alur kerja dan pelaporan. Adanya peningkatan pengetahuan dan keterampilan dalam pengelolaan Agrapana merupakan indicator capaian utama yang tercapai dalam aktivitas pengabdian masyarakat ini. Hal lain yang tampak adalah mulai dikelola akun media sosial Instagram (IG) yang berisikan informasi dan foto yang bertujuan untuk menarik minat wisatawan. Walaupun masih bertaraf rintisan, namun pengelola bersemangat dalam mengembangkan Agrapana.
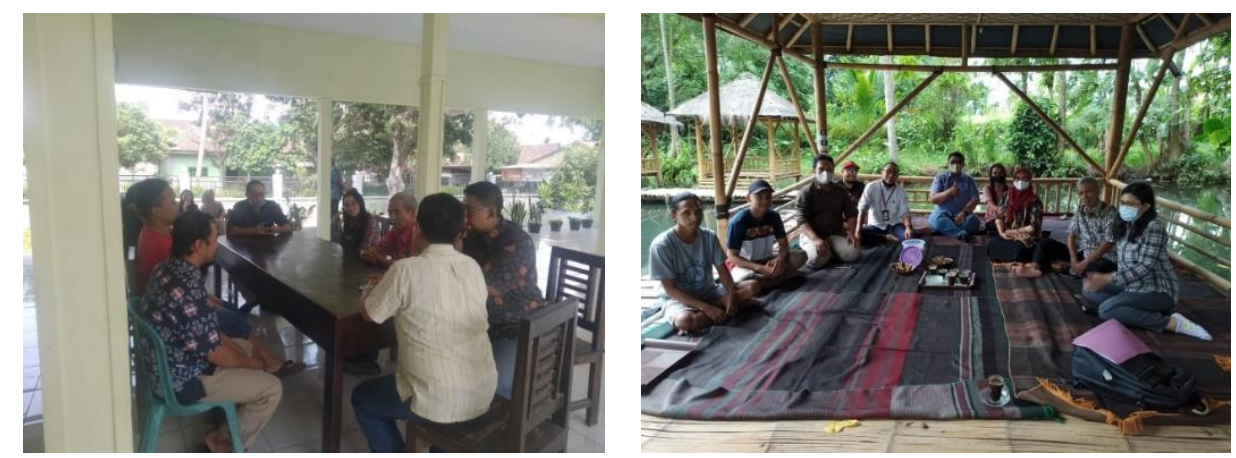

Gambar 2. Aktivitas Pendampingan yang diberikan pada BUMDes dan Pengelola Agrapana Sumber: Dokumentasi pribadi (2021)
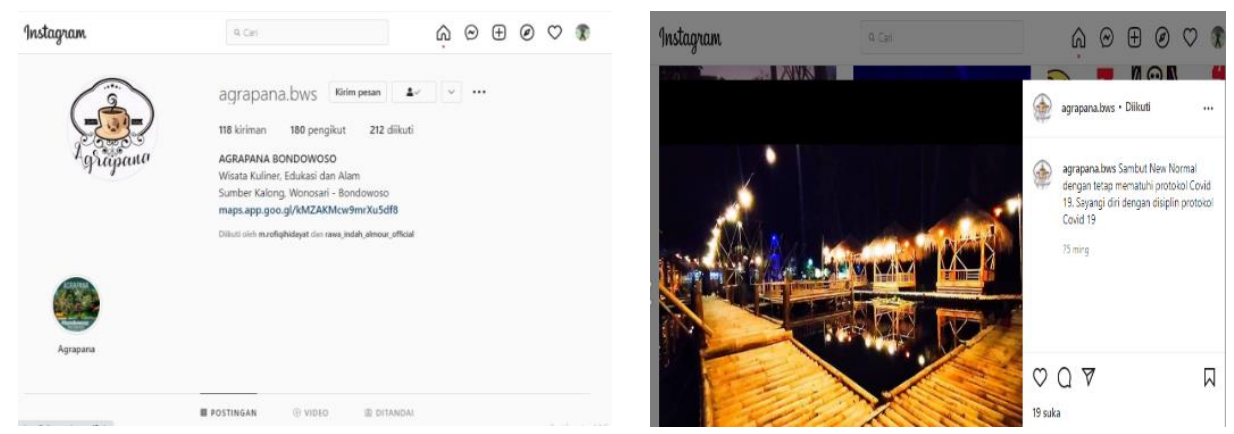

Gambar 3. Instagram Agrapana sebagai Media Informasi dan Promosi Wisata Sumber: Instagram.com

Pendampingan manajerial yang diberikan harus dibarengi dengan aktivitas pendampingan kepada masyarakat sekitar sebagai bentuk implementasi konsep community based tourism. Hasil pendampingan dan sosialisasi yang dilakukan masih dijumpai bahwa rasa kepemilikan akan destinasi dapat dikatakan rendah dan bahkan beberapa masyarakat menganggap belum penting menjadikan Sumber Kalong sebagai desa wisata. Masukan informasi dan wawancara yang mendalam dengan masyarakat yang demikian menjadikan program pengabdian yang dilakukan semakin penting untuk segera dibumikan pada masyarakat. Secara umum, warga sekitar tidak keberatan dengan adanya Agrapana, namun juga masyarakat masih belum sadar dan peduli tentang bagaimana menjaga dan memiliki aset desa. Pekerjaan rumah ini, yang menjadikan program pengabdian masyarakat harus terus dilakukan dengan berfokus pada kondisi masyarakat dan pelibatan masyarakat. Selain itu, masyarakat juga memandang bahwa Agrapana belum menjanjikan peluang ekonomi yang signifikan sehingga perlu usaha keras untuk mewujudkan tagline Agrapana Melesat.

Walaupun demikian, masyarakat ternyata juga memiliki sedikit mimpi yaitu bagaimana Agrapana dapat hidup selaras dengan masyarakat yang mayoritas petani, artinya dengan 
hadirnya Agrapana tidak merusak lahan dan komoditas pertanian namun dapat bersinergi dan menjadi satu kesatuan destinasi sekaligus tidak mengubah cara hidup masyarakat secara mendasar. Hal ini sesuai dengan konsep pembangunan pariwisata berkelanjutan dengan pendekatan community based tourism (Andini, 2013; Nurwanto, 2020). Hasil pendampingan juga menunjukkan bahwa masyarakat mulai tergugah namun masih perlu dukungan yang sinergi yang besar dengan kerangka pentahelix yaitu sinergi yang melibatkan akademisi, pemerintah, komunitas, industri pariwisata dan media.

Sebagai kegiatan terakhir aktivitas pengabdian kepada masyarakat di desa Sumber Kalong dilakukan pendampingan mengenai hospitality secara sederhana dalam hal kebersihan lingkungan tempat wisata, dan fasilitas daya tarik. Kebersihan dan kenyamanan merupakan salah satu dimensi dalam sapta pesona (Hendriyati, 2020). Kebersihan secara umum mampu meningkatkan citra destinasi dan membangun kenangan positif tentang destinasi (Mohaidin et al., 2017). Kegiatan pengabdian yang dilakukan memberikan bantuan dalam bentuk tempat sampah yang dikerjakan oleh warga desa setempat dari ban bekas dan membangun pagar hidup atau taman yang dikerjakan dan melibatkan masyarakat sekitar. Aktivitas ini dilakukan dalam rangka membangun kesadaran warga akan sense of belonging Agrapana sekaligus sebagai sarana membangun estetika dan kebersihan destinasi

\section{KESIMPULAN}

Pembangunan desa wisata dengan pendekatan community based tourism merupakan aktivitas yang bersifat holistik dan membutuhkan proses serta waktu. Membangun kesadaran merupakan salah satu tugas pendidikan kepada masyarakat dalam bentuk pengabdian berbasis desa binaan. Aktivitas sosialisasi dan pendampingan yang dilakukan dapat disimpulkan berjalan dengan baik dan lancar serta mitra merasa terbantu dan merespon positif atas kegiatan pengabdian ini. Hal ini tampak dari antusiasme perangkat desa dan pengelola Agrapana yaitu BUMDes dan warga sekitar untuk mengikuti program yang dilakukan. Perubahan yang dirasakan juga mulai tampak yaitu kemampuan manajerial dari pihak desa dan BUMDes serta mulai menata bagaimana membangun destinasi wisata berbasis desa, selain itu mulai muncul kesadaran masyarakat desa akan pentingnya desa wisata dan penambahan beberapa sarana untuk menunjang keberlangsungan desa wisata. Evaluasi program pengabdian kepada masyarakat setelah dianalisis yaitu perlu penguatan kesadaran kepada masyarakat sekitar tentang pentingnya desa wisata dan bagaimana desa wisata dapat menjadi multiplier effect bagi perekonomian setempat.

\section{UCAPAN TERIMA KASIH}

Ucapan terimakasih kami sampaikan kepada Lembaga Penelitian dan Pengabdian kepada Masyarakat Universitas Jember atas kesempatan yang diberikan dalam bentuk hibah pengabdian kepada masyarakat program desa binaan. Selain itu ucapan terimakasih juga kami sampaikan pada Dekan Fakultas Ekonomi dan Bisnis Universitas Jember atas ijin dan kesempatan yang diberikan untuk melaksanakan aktivitas tridharma perguruan tinggi dalam bentuk pengabdian kepada masyarakat. Ucapan terimakasih khususnya pada seluruh warga desa Sumber Kalong Kecamatan Wonosari Kabupaten Bondowoso atas partisipasi aktif dan kerjasama positif selama ini, berikutnya pada kelompok riset (keris) Tourism Management \& Community Development (Risma Code) sebagai wahana berkumpul dan berpikir dalam kajian manajemen pariwisata dan pembangunan komunitas.

\section{DAFTAR PUSTAKA}

Andini, N. (2013). Pengorganisasian Komunitas dalam Pengembangan Agrowisata di Desa Wisata Studi Kasus: Desa Wisata Kembangarum, Kabupaten Sleman. Journal of Regional and City Planning, 24(3), 173-188. 
Dewi, M. H. U., Fandeli, C., \& Baiquni, M. (2013). Pengembangan Desa Wisata Berbasis Partisipasi Masyarakat Lokal Di Desa Wisata Jatiluwih Tabanan, Bali. Jurnal Kawistara, 3(2), 129-139. https://doi.org/10.22146/kawistara.3976

Ghony, M. D., \& Almanshur, F. (2012). Metodologi Penelitian Kualitatif. Ar-Ruzz Media.

Giampiccoli, A., Mtapuri, O., \& Dłużewska, A. (2020). Investigating the intersection between sustainable tourism and community-based tourism. Tourism, 68(4), 415-433. https://doi.org/10.37741/t.68.4.4

Hendriyati, L. (2020). Upaya Masyarakat di Desa Wisata Penglipuran dalam Menjalankan Sapta Pesona. Journal of Tourism and Economic, 3(1), 49-57.

Ma'ruf, A. (2020). Analisis Medan Kekuatan Terhadap Barapan Kebo Sebagai Atraksi Community based tourism (CBT) di Kabupaten Sumbawa Barat. Jurnal Kepariwisataan Indonesia, 14(1), 53-65. https://doi.org/10.47608/jki.v14i12020.53-65

Mohaidin, Z., Wei, K. T., \& Ali Murshid, M. (2017). Factors influencing the tourists' intention to select sustainable tourism destination: a case study of Penang, Malaysia. International Journal of Tourism Cities, 3(4), 442-465. https://doi.org/10.1108/IJTC-11-2016-0049

Nugraha, K. S. W. (2019). Experiential Marketing: Managing Tourist Satisfaction And Revisit Intention Bangsring Underwater Banyuwangi. International Journal of Scientific \& Technology Research, 8(11), 3475-3479.

Nurwanto. (2020). Evaluasi Dampak Pembangunan Pariwisata Menggunakan Konsep Community based tourism (CBT) di Kawasan Wisata Tebing Breksi. Jurnal Kepariwisataan Indonesia, 14(2), 109-124.

Permadi, L. A., Oktariyani, G. A. S., Negara, I. K., \& Manan, S. S. A. (2020). Peningkatan Kinerja Organisasi Kelompok Sadar Wisata di Desa Bonjeruk, Kecamatan Jonggat, Kabupaten Lombok Tengah. Jurnal PEPADU, 1(1), 85-89.

Soekarya, T. (2011). Peningkatan Ekonomi Kerakyatan melalui Pengembangan Desa Wisata. Suatu Masukan untuk Pengembangan di Kakaskasen Dea, teritip dan Punten (Issue Septmber). Kementerian Kebudayaan dan Pariwisata.

Suryaningsih, I. B., Sularso, A., \& Handriana, T. (2020). Manajemen Pemasaran Pariwisata dan Indikator Pengukuran (I. Fadah \& K. W. S. Nugraha (eds.)). Samudra Biru.

Syafi'i, M., \& Suwandono, D. (2015). Perencanaan Desa Wisata Dengan Pendekatan Konsep Community based tourism (CBT) Di Desa Bedono, Kecamatan Sayung, Kabupaten Demak. Ruang, 1(2), 51-60. https://doi.org/10.14710/ruang.1.2.61-70 


\section{Halaman Ini Dikosongkan}

